\title{
Critical Success Factors across the Stages of ERP System Implementation in Sohar University: A Case Study
}

\author{
Ahmad Saleh Shatat, \\ Faculty of Business, Sohar University, Oman
}

Naser Dana,

Department of Information Technology, Sohar University, Oman

\begin{abstract}
:
Enterprise Resource Planning (ERP) system is a great solution to many cutting-edge businesses if implemented successfully and if not will cause a gigantic destruction in the organization. This research paper describes the Critical Success Factors (CSFs) in ERP system implementation across the three implementation stages in Sohar University which are pre-implementation stage, implementation stage, and postimplementation stage. A case study approach was used to investigate the perceptions of the key stakeholders in the university to pinpoint the CSFs of the ERP project. Based on a review of the ERP literature and in-depth interviews with the key stakeholders, $10 \mathrm{CSF}$ for ERP implementation have been identified. These findings extend our understanding of the CSFs that are perceived as critical for the key stakeholders involved in introducing, installing, and updating ERP system I higher education setting.
\end{abstract}

Paper type: Research paper

Keywords: Critical Success Factors, Enterprise Resource Planning, ERP Implementation, Higher Education Institutions, Case Study 


\section{Introduction}

The operation of higher education sector is quite different from other types of organisations. Mainly, this s due to the complexity of purpose, spread out in structure and authority, high internal fragmentation, difficulties in measuring the output, and high degree of society dependency and autonomy (Rabaa'I, 2009; Pollock and Cornford, 2004). Additionally, there is an increasing number of higher education institutions are constantly under pressure to deliver elite mass education at low costs because of funding cuts but increased expectations from various stakeholders at the same time (Das and Dayal, 2016). In relation to that, the adoption of information technology that can improve organisational performance is often perceived as necessary to all organisations.

The implementation of Enterprise Resource Planning (ERP) presents opportunities for organisations to better manage resources and information flow because if properly implemented, an enterprise system streamlines data flows and allows personnel to have direct access real-time operational data (Nah and Lau, 2001). The adoption of ERP system has increased noticeably since the last three decades (Das and Dayal, 2016; Davenport, 1998; Rabaa'I, 2009) due to its efficiency and the growing need for an integrated enterprise system.

However, the implementation of ERP system poses challenges to organisations in terms of costs, process, planning, technology fit, and adoption (Das and Dayal, 2016). In line with many organisations, universities are moving from the legacy administrative system to the new integrated ERP solution, which facilitate the communication among different units within the campus by integrating information from all faculties and departments into the same database to ensure direct access to the same information by all units of the university (Beekhuyzen et al., 2002; Rabaa'I, 2009). The difficulties faced by higher education institutions in implementing ERP system are numerous (Das and Dayal, 2016; Rabaa'I, 2009) and thus there is a need to examine the factors that could lead to successful implementation of ERP system (Pollock and Cornford, 2004). A review of the existing literature in the implementation of ERP in higher education institutions found that there is a limited studies focusing on the critical success factors that could affect the implementation of ERP system in universities. For that reason, this paper aims to address the following research question: What are the critical success factors (CSFs) that universities should consider across the stages of ERP system implementation?

This study is expected to contribute towards identifying the key critical success factors that reduce the likelihood of ERP system failure to assist many universities to consider those factors across the stages of ERP system implementation which would help them to avoid ERP system failure and achieve effective usage of the ERP system.

\section{Literature review}

ERP system is a commercial software information system that integrates and unifies main business functions such as financial management, manufacturing, and human resource management in order to improve data consistency and integration of

International Journal of Management and Applied Research, 2016, Vol. 3, No. 1 
modular applications that support operational activities and business functions (Davenport, 1998; Morris and Venkatesh 2010; Parr and Shanks 2000; Tian and Xu, 2015). ERP system is designed to support both primary and support activities of a firm's value chain (Ranganathan and Brown, 2006; Tian and Xu, 2015). In short, a successfully implemented ERP system can results in improved performance, especially from the perspective of business administration and information management.

The strategic implications of ERP system to organisational performance are welldocumented (Bala and Venkatesh 2013; Cotteleer and Bendoly 2006; Dehning et al., 2007; Karimi et al. 2007; Morris and Venkatesh 2010; Ranganathan and Brown, 2006; Sykes et al. 2014). Studies have found ERP system impacts at organisational levels, such as market reactions (Ranganathan and Brown, 2006), return on sales (Dehning et al., 2007), order-fulfillment performance (Cotteleer and Bendoly 2006), as well as process efficiency and effectiveness (Karimi et al. 2007). More recently, scholars have found positive relationship between successful implementation of ERP and users' job satisfaction and individual performance (Bala and Venkatesh 2013; Morris and Venkatesh 2010; Sykes et al. 2014).

\subsection{ERP System in Higher Education Sector}

The adoption of ERP system in the higher education sector can be traced back to 1980s, where the higher education institutions recognised the need for integrating different administrative duties and functions into a more cost-effective and systematic approach (Rabaa'I, 2009). For decades, administrative activities such as scheduling, student administration, personnel management, facilities management, and financial systems have been supported by standalone legacy systems (Beheshti, 2006; Das and Dayal, 2016; Rabaa'I, 2009; Pollock and Cornford, 2004). Integrating or merging these separate legacy system is often cited as "costly" (Das and Dayal, 2016), "difficult" (Pollock and Cornford, 2004), and "challenging" (Rabaa'I, 2009).

The modular and standalone nature of these legacy systems is quite problematic for the higher education institutions because they need to customise the system to fit with different and unique needs to support lecturers and students in several services for teaching, timetabling, examinations, etc. that are not part of traditional generic ERP (Pollock and Cornford, 2004). Despite of the various difficulties associated with the implementation of ERP system in higher education institutions, the demand for a solution for integrating administrative duties in universities remains. In many universities in the united states, the ERP system are used for speeding up students' registration, on-line payment, generating reports for administration, track faculty teaching records, and checking lecturer and classroom availability for course scheduling (Beheshti, 2006). In short, the demand for an integrated enterprise system to manage administrative tasks for universities continues to grow, for the purpose of efficient information management and streamlined data processing.

International Journal of Management and Applied Research, 2016, Vol. 3, No. 1 


\subsection{Critical Success Factors of Implementing ERP}

Kronbichler et al. (2009) identified 78 critical success factors which can be grouped into 15 umbrella terms as presented in table 1. On the other hand, Gargeya and Brady (2005) proposed 6 CSFs during the process of ERP system implementation, which are: 1) working with functionality/maintained scope; 2) project team/ management support/ consultation; 3) internal readiness/ training; 4) dealing with organizational diversity; 5) planning/ development/ budgeting; and finally 6) adequate testing. Other academics suggest additional critical IT capabilities that allied with the CSFs for optimum outcomes of the ERP system implementation such as IT leadership, business system thinking, relationship building, architecture planning, contract facilitation, technology fixing, informed buying, supplier development and contract monitoring (Feeny and Willcocks, 1998). Taken these together, it can be argued that there are many different views regarding critical success factors lead to successful implementation of ERP. While some scholars take a more holistic view regarding CSFs (Kronbichler et al., 2009); some are more concerned with the internal environment (Gargeya and Brady, 2005), technical issues or IT capabilities (Feeny and Willcocks, 1998).

Table 1: Critical success factors found in Literature

\begin{tabular}{|c|c|}
\hline $\begin{array}{l}\text { Critical success factors } \\
\text { (Umbrella term) }\end{array}$ & Critical success factors found in literature reflects the umbrella term \\
\hline \multirow{6}{*}{$\begin{array}{l}\text { Top Management } \\
\text { Support }\end{array}$} & Top management support and championship \\
\hline & $\begin{array}{l}\text { Top Management Support and commitment to project fit to business } \\
\text { strategy }\end{array}$ \\
\hline & Project Team competence \\
\hline & Dedicated resources \\
\hline & Setup a team that is qualified and represents the various functional areas \\
\hline & Release of business-experts \\
\hline \multirow{6}{*}{ Teamwork } & ERP teamwork and composition \\
\hline & ERP team composition, skills and compensation \\
\hline & Use of consultants \\
\hline & Appropriate usage of consultants \\
\hline & Personnel \\
\hline & Balanced team \\
\hline \multirow{3}{*}{$\begin{array}{l}\text { Cooperation \& } \\
\text { Communication }\end{array}$} & Interdepartmental co-operation \\
\hline & Effective communication \\
\hline & Multi-site issues \\
\hline \multirow{7}{*}{ Business Plan \& Vision } & Clear understanding of strategic goals \\
\hline & Clear goals \& objectives \\
\hline & Motivation behind ERP implementation \\
\hline & Anticipated Benefits from ERP implementation Project \\
\hline & Management (of) expectations \\
\hline & Business case \\
\hline & Adequate ERP implementation strategy \\
\hline \multirow{6}{*}{ Project Management } & Good project scope management \\
\hline & Alignment of people, process, technology \\
\hline & Risk management \\
\hline & Definition of scope and goals \\
\hline & Formalized project plan / schedule \\
\hline & Agree on different project steps \\
\hline Project Champion / & Provide an efficient decision making process \\
\hline Empowered & Empowered decision makers \\
\hline Decision Makers & Steering committee \\
\hline
\end{tabular}

International Journal of Management and Applied Research, 2016, Vol. 3, No. 1 
Critical Success Factors across the Stages of ERP System Implementation in Sohar University: A Case Study

\begin{tabular}{|c|c|}
\hline \multirow[t]{4}{*}{ Vendor Support } & $\begin{array}{l}\text { Use of vendors development tools } \\
\text { Vendor's tools }\end{array}$ \\
\hline & $\begin{array}{l}\text { ERP software package selection / careful selection of the appropriate } \\
\text { package }\end{array}$ \\
\hline & System analysis, selection and technical implementation \\
\hline & Monitoring and evaluation of performance \\
\hline \multirow{7}{*}{$\begin{array}{l}\text { Technological } \\
\text { Infrastructure }\end{array}$} & Architecture choices \\
\hline & Suitability of software and hardware \\
\hline & Adequate ERP version \\
\hline & Adequate software configuration \\
\hline & Defining the architecture \\
\hline & Technological infrastructure \\
\hline & Careful package selection \\
\hline \multirow{3}{*}{ Software Development } & Software development, testing and troubleshooting \\
\hline & Reduce trouble shooting \\
\hline & Education on new business processes \\
\hline User Involvement / & User training \\
\hline \multirow[t]{2}{*}{ Training } & Extensive Education and Training \\
\hline & Scope of user training \\
\hline Business Process & BPR (Business Process Reengineering) \\
\hline \multirow[t]{2}{*}{ Reengineering } & Minimal customization \\
\hline & Change management programme and culture \\
\hline \multirow[t]{3}{*}{ Change Management } & Commitment to change \\
\hline & Create an environment that is ready for change \\
\hline & Trust between partners \\
\hline \multirow[t]{2}{*}{ Partnership } & Vendor partnership \\
\hline & ERP consultants/vendor/customer partnership \\
\hline \multirow{4}{*}{$\begin{array}{l}\text { Legacy Systems } \\
\text { Knowledge (Data } \\
\text { Analysis \& Conversion) }\end{array}$} & Appropriate business and IT legacy systems \\
\hline & Data accuracy \\
\hline & Adequate legacy systems knowledge \\
\hline & Data analysis and conversion \\
\hline Deliverable Dates / & Deliverable Dates \\
\hline Smaller Scope & Smaller Scope \\
\hline
\end{tabular}

Source: Kronbichler et al. (2009: 15)

Some scholars have categorised CSFs according to the implementation phases of ERP system (see table 2). Managerial supports are often perceived as critical for majority of the researchers in all phases of ERP system implementation; followed by teamwork, and project champion.

Table 2: Phases of ERP System Implementation

\begin{tabular}{|c|c|c|c|c|c|}
\hline Critical success factors & $\mathbf{a}$ & $\mathbf{b}$ & c & $\mathbf{d}$ & Implementation Phases \\
\hline Top Management Support & $\mathrm{x}$ & $\mathrm{X}$ & $\mathrm{X}$ & $\mathrm{x}$ & \multirow{9}{*}{ Pre-Implementation } \\
\hline Teamwork \& Composition & $\mathrm{x}$ & $\mathrm{x}$ & $\mathrm{x}$ & $\mathrm{x}$ & \\
\hline Project Champion / Empowered Decision Makers & $\mathrm{x}$ & $\mathrm{X}$ & $\mathrm{x}$ & $\mathrm{x}$ & \\
\hline Business Plan \& Vision & $\mathrm{x}$ & $\mathrm{X}$ & $\mathrm{x}$ & $\mathrm{x}$ & \\
\hline Project Management & & $\mathrm{X}$ & & $\mathrm{x}$ & \\
\hline $\begin{array}{l}\text { Architecture Choices, Technical Implementation, } \\
\text { Technological Infrastructure }\end{array}$ & & & $\mathrm{x}$ & $\mathrm{x}$ & \\
\hline Business Process Reorganization & $\mathrm{x}$ & & & $\mathrm{x}$ & \\
\hline Deliverable Dates / Smaller Scope & $\mathrm{x}$ & & & $\mathrm{x}$ & \\
\hline Partnership & & & $\mathrm{X}$ & $\mathrm{x}$ & \\
\hline Top Management Support & $\mathrm{X}$ & $\mathrm{X}$ & $\mathrm{X}$ & $\mathrm{x}$ & \multirow[t]{2}{*}{ Implementation } \\
\hline Teamwork \& Composition & $\mathrm{x}$ & $\mathrm{x}$ & $\mathrm{X}$ & $\mathrm{x}$ & \\
\hline
\end{tabular}

International Journal of Management and Applied Research, 2016, Vol. 3, No. 1 
Critical Success Factors across the Stages of ERP System Implementation in Sohar University: A Case Study

\begin{tabular}{|c|c|c|c|c|c|}
\hline $\begin{array}{l}\text { (Interdepartmental-) Cooperation \& } \\
\text { Communication }\end{array}$ & & & $\mathrm{x}$ & $\mathrm{x}$ & \\
\hline Project Management & & $\mathrm{x}$ & & $\mathrm{x}$ & \\
\hline Project Champion / Empowered Decision Makers & $\mathrm{X}$ & $\mathrm{X}$ & & $\mathrm{x}$ & \\
\hline Vendor Support & & & $\mathrm{x}$ & $\mathrm{x}$ & \\
\hline Software Development, Testing, Troubleshooting & & & & $\mathrm{x}$ & \\
\hline User Involvement / Training & & & $\mathrm{x}$ & $\mathrm{x}$ & \\
\hline Business Process Reorganization & $\mathrm{x}$ & $\mathrm{x}$ & & $\mathrm{x}$ & \\
\hline Change Management & $\mathrm{x}$ & & & $\mathrm{x}$ & \\
\hline Deliverable Dates / Smaller Scope & $\mathrm{X}$ & & & $\mathrm{x}$ & \\
\hline Legacy Systems Knowledge & & $\mathrm{X}$ & & $\mathrm{x}$ & \\
\hline Top Management Support & $\mathrm{X}$ & $\mathrm{x}$ & $\mathrm{X}$ & $\mathrm{x}$ & \multirow{9}{*}{ Post-Implementation } \\
\hline Teamwork \& Composition & $\mathrm{X}$ & $\mathrm{x}$ & & $\mathrm{x}$ & \\
\hline $\begin{array}{l}\text { (Interdepartmental-) Cooperation \& } \\
\text { Communication }\end{array}$ & & & $\mathrm{x}$ & $\mathrm{x}$ & \\
\hline Project Champion / Empowered Decision Makers & $\mathrm{X}$ & & & $\mathrm{x}$ & \\
\hline Vendor Support & & & $\mathrm{x}$ & $\mathrm{x}$ & \\
\hline User Involvement / Training & & $\mathrm{x}$ & $\mathrm{x}$ & $\mathrm{x}$ & \\
\hline Business Process Reorganization & & & & $\mathrm{x}$ & \\
\hline Deliverable Dates / Smaller Scope & $\mathrm{x}$ & & & $\mathrm{x}$ & \\
\hline Change Management & $\mathrm{X}$ & $\mathrm{x}$ & & $\mathrm{x}$ & \\
\hline
\end{tabular}

Sources: a: Parr \& Shanks (2000), b: Shanks et al. (2000),

c: Somers \& Nelson (2004), d: Kronbichler et al. (2009)

Somers and Nelsons (2004) identified 22 CSFs into 2 categories: Key Players and Key Activities. The Key Players include any person or any group of people that affected by the implementation of the project, including: top management, project champion, implementation consultants, project team, customer, and vendor. Whereas Key Activities include the following: management of expectations, project management, selection of appropriate package, user training, customization, data conversion, business process reengineering, architecture definition, dedicating resources, establishing clear goals and objectives, education on new business processes, interdepartmental communication, and interdepartmental cooperation.

A critical view of the abovementioned studies (Feeny and Willcocks, 1998; Gargeya and Brady, 2005; Kronbichler et al., 2009; Somers and Nelsons, 2004) reveal ten commonly cited CSFs: top management support; teamwork; project champion; project management; business plan; vendor support; user training; change management; business process reengineering; and communication. In the following section, ten most commonly cited CSFs are explained in order to provide a better overview of the CSF.

\subsubsection{Top Management Support}

Top management support is one of the most frequently factors that support the success of ERP system (Kronbichler et al., 2009; Parr and Shanks, 2000; Shanks et al. 2000; Somers and Nelson, 2004). Nah and Lau (2001) noted that top management support is a very important factor that helps companies to successfully implement the ERP system. Top management support is the key for the successful implementation of the ERP system (Loonam and McDonagh, 2005). Top management is committed to support the ERP system across the implementation stages and they are responsible for the success of this project (Beheshti, 2006).

International Journal of Management and Applied Research, 2016, Vol. 3, No. 1 
According to Burca et al. (2005) top management is responsible to direct and monitor the ERP project and the associated training programme, and to make the employees more involved in the project and the related programme to run the ERP system project smoothly. Top management need to support the implementation team effectively and empower their employees through continuous training in order to accept the idea of change.

\subsubsection{Teamwork \& Composition}

Teamwork \& Composition have been considered by many researchers and practitioners as one of the most critical success factor of ERP system implementation where all functional departments of the enterprise must be involved in the implementation process, and all staff, experts, consultants, and end-users must cooperate with each other to complete the project successfully (King, 2005; Loh and Koh, 2004; Remus, 2007).

The success of the project relies on the skills and the knowledge of the project team members and on the experience of the project manager (Al-Mashari et al., 2006). Therefore, the selection of the project team members should be appropriate and carefully approached to pick the most skilled and knowledgeable staff with the right experienced manager (Somers and Nelsons, 2004). Forming the right project team by selecting the right members who deeply understand the business process and have long experience in the organization is crucial.

\subsubsection{Project Management}

A successful implementation of ERP system requires an effective project management (Rabaa'I, 2009). Project management is the process of ongoing management of the implementation plan. It involves planning, allocating responsibilities, training, and determination of the success measures. Project management needs a steering committee which made up of senior management from different departments, project management, and the system end-users who should be involved in several phases of the ERP system lifecycle. The project management should follow a clear methodology and appropriate management structure in order to achieve successful implementation of ERP project (Nah and Lau, 2001; Somers and Nelson, 2004; Finney and Corbett, 2007). Typically, before the implementation of the ERP system, project managers must understand the ability of the company to adopt the system and achieve optimum use. The success of the project depends on the company readiness in different aspects such as budget, time, infrastructure, etc. (Schniederjans and Kim, 2003). Therefore, companies must be ready prior to this huge implementation to gain better business performance.

\subsubsection{Change Management}

Change management is another frequently cited factor that determines the success of ERP system implementation (Rabaa'I, 2009). Shaul and Taber (2012) noted that, the implementation of new ERP system is typically encountered with high resistance form the end users as they are worried that the new system might change many of

International Journal of Management and Applied Research, 2016, Vol. 3, No. 1 
their routine job lifestyle such as ease of use, importance, job status, responsibilities, access to critical information, and job security. However, this problem should be dealt with during the planning phase and through extensive change management programme.

Burca et al., (2005) stated that many of the employees need a change management programme to help them to understand and accept the new changes that will occur in their operations. Therefore, to achieve a successful ERP implementation it becomes mandatory to educate and train the users of the ERP system on the new change that affects their daily tasks (Park and Kusiak, 2005).

\subsubsection{Business Process Reengineering}

To a great extent, the success of ERP system depends on the careful planning and successful management of the ERP project, refinement of the reengineering of the organization, and the post-implementation alignment of the ERP system with the organization's strategic direction (Katerattanakul et al., 2006).

Reengineering of the business process is fundamental to match the requirement of the new system (Remus, 2007). Mismatching between the company business processes and new system functionality needs either customization of the system to match the company processes or redesigning the company processes to be in line with the new system. However, the project manager should decide whether to customize the system or to change the business processes of the company which is usually a hard decision. Usually the customization of the system is not a good practice because it might end up with low system performance. Most of ERP vendors provide "Best Practice" or something call "Vanilla System" which standardized the business processes to end up with best system performance (Kronbichler et al., 2009).

\subsubsection{Business Plan \& Vision}

Nah and Lau (2001) noted that the business vision must be stated clearly, and measurable goals of the ERP project should be clear and understandable. Clear project plan with comprehensive vision that can fit with the organizational goals are critical to ensure the success of the ERP project implementation. The project plan will provide a clear guidance to the project team which will help them to concentrate on the project goals and will avoid any misunderstanding of the project requirements and that eventually lead to successful ERP system implementation (Kronbichler et al., 2009).

\subsubsection{User Involvement \& Training}

The complexity of ERP system requires dedication and involvement of users and thus it is important for employees to be involved in all stages of implementing ERP system (Kronbichler et al., 2009). The users of ERP system need to understand the benefits of using ERP system and aware of the technical know-how in order to reduce the level of user resistance to new technology and resistance to change (Rabaa'I, 2009). In relation to that, extensive education and training programme becomes essential

International Journal of Management and Applied Research, 2016, Vol. 3, No. 1 
during the process of implementing ERP system (Gargeya and Brady, 2005; Kronbichler et al., 2009; Rabaa'I, 2009). However, if companies ignore the users' involvement and training during the ERP system project this might lead to failure to implement ERP system. Therefore, extensive attention must be given to the users of the system to avoid negative results (Stewart et al., 2000). The users training programme should be conducted regularly to involve the users with the system and to introduce the system gradually to them. This will help the users to accept the idea of change and use the system effectively (Burca et al., 2005).

\subsubsection{Cooperation \& Communication}

Cooperation and communication is considered as essential to the success of implementing ERP system (Kronbichler et al., 2009). Effective communication should take place at all stages of implementing ERP system so that employees could be aware of the progress and understand the benefits of having enterprise system in place (Rabaa'I, 2009). It is equally important to define goals and communicate the results to the involved participants (Kronbichler et al., 2009). This can be done via face to face communication such as regular update meetings or asynchronous communication such as email or posters in conspicuous locations (Rabaa'I, 2009).

\subsubsection{Vendor support}

Vendors play an important role in the successful implementation of ERP system (Somers and Nelsons, 2004). In Australia 86\% of the universities replaced their legacy system with ERP solution, and 38\% of the Australian universities had selected ERP system from same vendor to ensure complete integration within the university campus and among several universities in the same country (Beekhuyzen et al., 2002). Selecting ERP system from the same vendor across all universities in the country will ensure integration and standardization in different aspects in the higher education sector.

\subsubsection{Project Champion}

A project champion is equivalent to a project leader, "who made a decisive contribution to the innovation by actively and enthusiastically promoting its progress through critical stages in order to obtain resources and/or active support from top management" (Kronbichler et al., 2009: 17). According to Somers and Nelsons, (2004), a project champion is one of the key players during the process of adopting ERP system. As Davenport (1998: 131) stated: "Only a general manager is equipped to act as the mediator between the imperatives of the technology and the imperatives of business. If the development of an enterprise system is not carefully controlled by management, management may soon find itself under the control of the system". This highlights the importance of having a decision maker in the process of introducing and installing an ERP system.

International Journal of Management and Applied Research, 2016, Vol. 3, No. 1 


\section{Case Study}

In this study we adopted a single case study approach as the main research method to particularly focus on one experience and to deeply understand the behaviour of one university during the ERP system implementation. This will help us to learn more from one major exercise in the higher education sector and other universities will also learn from this particular case within the Omani context. Sohar University is the first private university and considered as the second university in the Sultanate of Oman after Sultan Qaboos University where it represents a major part in higher education industry. It includes six faculties and several departments such as registration, finance, human resource, purchasing, and IT services.

The implementation of ERP system in Sohar University was to some extent a complex project where the implementation of the project completed in more than three years with several challenges. This is mainly because the university has its own teaching approach, it uses the units system where the weight of each course is equal to two unites and each unit is equal to two teaching hours. The delivery mode of the two unites is two hours lecture and two hours tutorial where the tutorial must be deliver to the same group of students in all different courses. This unique teaching approach creates major challenges to the system vendor which lead to high level of customization on the original system and eventually forced the system vendor to make a new and unique version that can fit with the unique university requirements.

Sohar University adopted ERP solution to streamline its daily business process, provide integration between departments and faculties within the campus particularly between registration \& financial departments and the entire faculties, boost information access, facilitate the registration process and scheduling, provide different services to staff and students, response to different pressures in the surrounding environment and to several social and economic factors, and eventually manage the institution in a better way to gain a strategic advantage.

Since it's a case study approach in-depth analysis of all dimensions of the ERP system has been carried out and various interviews has been conducted with the key stakeholders of the university across all departments and faculties to identify the key critical success factor of the ERP system across the implementation phases. During the interview several questions were asked to the interviewees and one of the important tasks that they should complete is to rank the most CSFs in each implementation stage.

This study went through three parts of the qualitative methodology which are in-depth semi-structured interviews with the key stakeholders, in-depth analysis of the written project documents, and direct observation in the field was conducted to illustrate some important aspects of the system. The interviewees were given a list of CSFs to identify the most important factors in each implementation stage particularly in the stage that the interviewee was more involved in.

The selection of the interviewees was based on three criteria; the first one was the degree of participation and involvement in one or more of the project phases, second the importance of his/her decision on the project progress, third the extent to which

International Journal of Management and Applied Research, 2016, Vol. 3, No. 1 
his ไher involvement or decision affects the project continuation. Therefore, the interview was with the university vice chancellor and his deputy, faculty deans, professors, department managers, end users, and some members of the project team including one from the system provider.

Based on the above criteria 13 interviewees were selected for semi-structured one to one interview to represent the three stages of the ERP project implementation, the number of interviewees was in line with other similar studies. The length of the interview with each interviewee was around one hour and thirty minutes in average and with some interviewees the interview was extended to two hours. From the list of the CSFs which was given to the interviewees they were asked to identify what are the factors that were considered in each phase of the ERP system implementation and what factors were extremely considered but were not important in one of the stages and should be considered in another stage. The interviewees were also asked to rank the top CSFs in each stage based on their own experience with the ERP project.

\section{Analysis and Findings}

All interviews were recorded in digital recorder, then the transcript compiled into several subjects excluding all errors, gaps, and incomplete information. The interpretation of the gathered information has been completed without eliminating the facts that may not fit with the initial expectations of the research. The interpretation of the data also evaluates the differences and similarities among several responses.

Table 3 presents the top ten CSFs that ranked by the university stakeholders as the most important factors in the ERP system implementation. All key stakeholders agreed on these 10 factors as the top 10 critical factors that can support the project team to achieve successful implementation of the ERP system in Sohar University.

Table 3: Ranking of Critical Success Factors

\begin{tabular}{llc}
\hline Rank & Critical Success Factors & Mean \\
\hline 1 & Top Management Support & 4.51 \\
2 & Teamwork \& Composition & 4.39 \\
3 & Project Champion & 4.23 \\
4 & Project Management & 4.05 \\
5 & Business Plan \& Vision & 4.01 \\
6 & Vendor Support & 3.89 \\
7 & User Involvement / Training & 3.74 \\
8 & Change Management & 3.51 \\
9 & Business Process Reorganization & 3.33 \\
10 & Cooperation \& Communication & 3.17 \\
\hline Note: Higher rank means the factor is ranked unimportant, \\
anking is based on l=the most important and 10=the most unimportant.
\end{tabular}

The above data indicates that top management support is the most important factor in ERP system implementation followed by teamwork \& composition and project champion, then the other factors follow them respectively. In fact, all ten CSFs are important throughout the ERP system implementation, however, to minimize the

International Journal of Management and Applied Research, 2016, Vol. 3, No. 1 
Critical Success Factors across the Stages of ERP System Implementation in Sohar University: A Case Study

likelihood of system failure and to ensure entire success of the system this research has identified the required CSFs for each phase of the ERP system implementation. Table 4 presents the top CSFs ranked by the university stakeholders in each stage of the ERP system implementation.

Table 4: Top CSFs during the ERP System Implementation Phases

\begin{tabular}{|c|c|c|c|c|c|c|c|c|c|c|c|c|c|c|}
\hline CSFs & 1 & 2 & 3 & 4 & 5 & 6 & 7 & 8 & 9 & 10 & 11 & 12 & 13 & Phases \\
\hline Top Management Support & $\mathrm{x}$ & $\mathrm{x}$ & $\mathrm{x}$ & $\mathrm{x}$ & $\mathrm{x}$ & $\mathrm{x}$ & $\mathrm{x}$ & $\mathrm{x}$ & $\mathrm{x}$ & $\mathrm{X}$ & $\mathrm{X}$ & $\mathrm{x}$ & $\mathrm{x}$ & \multirow{9}{*}{$\begin{array}{c}\text { Pre- } \\
\text { Implementation }\end{array}$} \\
\hline Teamwork \& Composition & $\mathrm{X}$ & $\mathrm{x}$ & $\mathrm{x}$ & $\mathrm{x}$ & $\mathrm{X}$ & $\mathrm{x}$ & & & $\mathrm{x}$ & $\mathrm{x}$ & & $\mathrm{x}$ & $\mathrm{X}$ & \\
\hline $\begin{array}{l}\text { Project Champion / Empowered } \\
\text { Decision Makers }\end{array}$ & $\mathrm{x}$ & $\mathrm{x}$ & $\mathrm{x}$ & $\mathrm{x}$ & & & & & & & & $\mathrm{x}$ & $\mathrm{x}$ & \\
\hline Business Plan \& Vision & $\mathrm{x}$ & $\mathrm{x}$ & $\mathrm{x}$ & $\mathrm{x}$ & $\mathrm{x}$ & & $\mathrm{x}$ & $\mathrm{x}$ & $\mathrm{x}$ & & & $\mathrm{X}$ & $\mathrm{x}$ & \\
\hline Project Management & & & $\mathrm{x}$ & $\mathrm{x}$ & $\mathrm{X}$ & & & & & & & & $\mathrm{x}$ & \\
\hline $\begin{array}{l}\text { Architecture Choices, Technical } \\
\text { Implementation, Technological } \\
\text { Infrastructure }\end{array}$ & $\mathrm{x}$ & $\mathrm{x}$ & $\mathrm{x}$ & $\mathrm{x}$ & $\mathrm{x}$ & $\mathrm{x}$ & $\mathrm{x}$ & $\mathrm{x}$ & $\mathrm{x}$ & & & $\mathrm{x}$ & $\mathrm{x}$ & \\
\hline Business Process Reorganization & $\mathrm{x}$ & $\mathrm{x}$ & $\mathrm{x}$ & $\mathrm{x}$ & $\mathrm{x}$ & & & & $\mathrm{x}$ & & & $\mathrm{x}$ & $\mathrm{x}$ & \\
\hline $\begin{array}{l}\text { Deliverable Dates / Smaller } \\
\text { Scope }\end{array}$ & & $\mathrm{x}$ & $\mathrm{x}$ & $\mathrm{x}$ & & & & & & & & $\mathrm{x}$ & $\mathrm{x}$ & \\
\hline Partnership & $\mathrm{x}$ & $\mathrm{x}$ & & & & & & & & & & $\mathrm{x}$ & $\mathrm{x}$ & \\
\hline Top Management Support & $\mathrm{x}$ & $\mathrm{x}$ & $\mathrm{x}$ & $\mathrm{x}$ & $\mathrm{x}$ & $\mathrm{x}$ & $\mathrm{x}$ & $\mathrm{x}$ & $\mathrm{x}$ & $\mathrm{x}$ & $\mathrm{X}$ & $\mathrm{X}$ & $\mathrm{x}$ & \multirow{12}{*}{ Implementation } \\
\hline Teamwork \& Composition & $\mathrm{x}$ & $\mathrm{x}$ & $\mathrm{x}$ & $\mathrm{x}$ & $\mathrm{x}$ & $\mathrm{x}$ & $\mathrm{x}$ & $\mathrm{x}$ & $\mathrm{x}$ & $\mathrm{x}$ & $\mathrm{X}$ & $\mathrm{X}$ & $\mathrm{x}$ & \\
\hline $\begin{array}{l}\text { (Interdepartmental-) Cooperation } \\
\text { \& Communication }\end{array}$ & $\mathrm{x}$ & $\mathrm{x}$ & $\mathrm{x}$ & $\mathrm{x}$ & $\mathrm{X}$ & $\mathrm{x}$ & $\mathrm{x}$ & $\mathrm{x}$ & $\mathrm{x}$ & $\mathrm{x}$ & $\mathrm{x}$ & $\mathrm{x}$ & $\mathrm{x}$ & \\
\hline Project Management & $\mathrm{x}$ & $\mathrm{x}$ & $\mathrm{x}$ & $\mathrm{x}$ & $\mathrm{x}$ & $\mathrm{x}$ & $\mathrm{x}$ & $\mathrm{x}$ & $\mathrm{x}$ & $\mathrm{x}$ & $\mathrm{X}$ & $\mathrm{x}$ & $\mathrm{x}$ & \\
\hline $\begin{array}{l}\text { Project Champion / Empowered } \\
\text { Decision Makers }\end{array}$ & $\mathrm{x}$ & $\mathrm{x}$ & $\mathrm{x}$ & $\mathrm{x}$ & $\mathrm{X}$ & $\mathrm{x}$ & $\mathrm{X}$ & $\mathrm{x}$ & $\mathrm{x}$ & $\mathrm{x}$ & $\mathrm{X}$ & $\mathrm{x}$ & $\mathrm{X}$ & \\
\hline Vendor Support & $\mathrm{x}$ & $\mathrm{x}$ & $\mathrm{x}$ & $\mathrm{x}$ & $\mathrm{x}$ & $\mathrm{x}$ & $\mathrm{x}$ & $\mathrm{x}$ & $\mathrm{x}$ & $\mathrm{x}$ & $\mathrm{x}$ & $\mathrm{x}$ & $\mathrm{x}$ & \\
\hline $\begin{array}{l}\text { Software Development, Testing, } \\
\text { Troubleshooting }\end{array}$ & & & $\mathrm{x}$ & $\mathrm{x}$ & $\mathrm{x}$ & $\mathrm{x}$ & & & & & & $\mathrm{x}$ & $\mathrm{x}$ & \\
\hline User Involvement / Training & $\mathrm{x}$ & $\mathrm{x}$ & $\mathrm{x}$ & $\mathrm{x}$ & $\mathrm{X}$ & $\mathrm{x}$ & $\mathrm{X}$ & $\mathrm{x}$ & $\mathrm{x}$ & $\mathrm{X}$ & $\mathrm{x}$ & $\mathrm{x}$ & $\mathrm{x}$ & \\
\hline Business Process Reorganization & $\mathrm{x}$ & $\mathrm{x}$ & $\mathrm{x}$ & $\mathrm{x}$ & $\mathrm{x}$ & $\mathrm{x}$ & $\mathrm{x}$ & $\mathrm{x}$ & $\mathrm{x}$ & $\mathrm{x}$ & $\mathrm{x}$ & $\mathrm{x}$ & $\mathrm{x}$ & \\
\hline Change Management & $\mathrm{x}$ & $\mathrm{x}$ & $\mathrm{x}$ & $\mathrm{x}$ & $\mathrm{X}$ & $\mathrm{x}$ & $\mathrm{x}$ & $\mathrm{x}$ & $\mathrm{x}$ & $\mathrm{X}$ & $\mathrm{x}$ & $\mathrm{x}$ & $\mathrm{x}$ & \\
\hline $\begin{array}{l}\text { Deliverable Dates / Smaller } \\
\text { Scope }\end{array}$ & & $\mathrm{x}$ & & $\mathrm{x}$ & & & & & & & & & $\mathrm{x}$ & \\
\hline Legacy Systems Knowledge & $\mathrm{x}$ & $\mathrm{x}$ & $\mathrm{x}$ & $\mathrm{x}$ & $\mathrm{x}$ & $\mathrm{x}$ & & & & & & $\mathrm{x}$ & $\mathrm{x}$ & \\
\hline Top Management Support & $\mathrm{x}$ & $\mathrm{x}$ & $\mathrm{x}$ & $\mathrm{x}$ & $\mathrm{x}$ & & & & $\mathrm{x}$ & $\mathrm{x}$ & $\mathrm{x}$ & & $\mathrm{x}$ & \multirow{9}{*}{$\begin{array}{c}\text { Post- } \\
\text { Implementation }\end{array}$} \\
\hline Teamwork \& Composition & & $\mathrm{x}$ & & $\mathrm{x}$ & $\mathrm{x}$ & & & & & & $\mathrm{x}$ & & $\mathrm{x}$ & \\
\hline $\begin{array}{l}\text { (Interdepartmental-) Cooperation } \\
\text { \& Communication }\end{array}$ & $\mathrm{x}$ & $\mathrm{x}$ & $\mathrm{x}$ & $\mathrm{x}$ & $\mathrm{X}$ & $\mathrm{x}$ & $\mathrm{x}$ & $\mathrm{x}$ & $\mathrm{x}$ & $\mathrm{x}$ & $\mathrm{x}$ & $\mathrm{x}$ & $\mathrm{x}$ & \\
\hline $\begin{array}{l}\text { Project Champion / Empowered } \\
\text { Decision Makers }\end{array}$ & & $\mathrm{x}$ & $\mathrm{x}$ & $\mathrm{x}$ & & & & & & & & & $\mathrm{X}$ & \\
\hline Vendor Support & $\mathrm{x}$ & $\mathrm{x}$ & $\mathrm{x}$ & $\mathrm{x}$ & $\mathrm{X}$ & $\mathrm{x}$ & $\mathrm{x}$ & $\mathrm{x}$ & $\mathrm{x}$ & $\mathrm{x}$ & $\mathrm{x}$ & $\mathrm{x}$ & $\mathrm{x}$ & \\
\hline User Involvement / Training & $\mathrm{x}$ & $\mathrm{x}$ & $\mathrm{x}$ & $\mathrm{x}$ & $\mathrm{x}$ & $\mathrm{x}$ & $\mathrm{x}$ & $\mathrm{x}$ & $\mathrm{x}$ & $\mathrm{x}$ & $\mathrm{x}$ & $\mathrm{x}$ & $\mathrm{x}$ & \\
\hline Business Process Reorganization & & & & $\mathrm{x}$ & $\mathrm{x}$ & & & & $\mathrm{x}$ & & & & & \\
\hline $\begin{array}{l}\text { Deliverable Dates / Smaller } \\
\text { Scope }\end{array}$ & $\mathrm{x}$ & $\mathrm{x}$ & $\mathrm{x}$ & $\mathrm{x}$ & $\mathrm{X}$ & & $\mathrm{x}$ & $\mathrm{x}$ & $\mathrm{x}$ & & & $\mathrm{X}$ & $\mathrm{x}$ & \\
\hline Change Management & $\mathrm{x}$ & $\mathrm{x}$ & $\mathrm{x}$ & $\mathrm{x}$ & $\mathrm{x}$ & $\mathrm{x}$ & $\mathrm{x}$ & $\mathrm{x}$ & $\mathrm{x}$ & $\mathrm{x}$ & $\mathrm{x}$ & $\mathrm{x}$ & $\mathrm{x}$ & \\
\hline
\end{tabular}

Legend (Interviewees): 1: Vice Chancellor, 2: Deputy Vice Chancellor, 3: Dean Faculty of Engineering, 4: Registration Manager, 5: Finance Manager, 6: DB Administrator, 7: Professor in Faculty of Business, 8: Professor in Faculty of IT, 9: HR Manager, 10: Estates Manager, 11: Stores Manager, 12: Vendor Software Specialist, 13: Project Manager.

$\mathbf{x}=$ important

International Journal of Management and Applied Research, 2016, Vol. 3, No. 1 
According to table 4 the most CSFs in the three implementation phases are Top Management Support, Teamwork \& Composition, and Project Champion/ Empowered Decision Makers respectively. Business Plan \& Vision must be stated clearly in the pre-implementation phase to ensure the success of the ERP project in the post-implementation phase. Project management is a crucial factor mainly in the implementation phase then pre-implementation phase. Factors such as Vendor Support, User InvolvementlTraining, and Change Management are tremendously critical in the second and last stages of the ERP system implementation and that's because the respondents believe that the system vendor must be available during the implementation stage and ready for any support that might occur during this phase.

The system users must be part of the implementation to understand the system and to get proper training on the system in order to share the right views with the project team to end up with a system that contain all required functionalities. A clear change management plan is needed in this stage to overcome the expected change resistance. There are several factors must be considered across the three stages of the ERP system implementation, and some other factors must be taken into account in two phases, and other factors only in one phase. Top Management Support should exist from the first day that the ERP project starts until the end of the system implementation lifecycle. Project management, Change Management, Teamwork, User involvement must occur in at least two phases. And very high attention must be given to the Clear Goals \& Objectives factor in the pre-implementation stage. However, it's not a wise move that the project manager neglect one of the critical factors that is crucial in a particular phase because that might lead to unsuccessful project.

The respondents were also asked to rank the CSFs based on the importance of each factor in the ERP project. A five-point Likert-type scale rating from 1=Not important to 5= Very important was used for ranking each CSFs during the ERP system implementation. Table 5 shows the mean and standard deviation for the 10 CSFs which indicates the order of importance of each factor in the three implementation phases.

Table 5: CSFs mean ranking based on the degree of importance in the ERP Implementation

\begin{tabular}{llccc}
\hline \multicolumn{1}{c}{ CSFs } & Mean & Std. Dev. & Phases \\
\hline 1. & Top Management Support & 4.51 & 1.24 & $1,2,3$ \\
2. Teamwork \& Composition & 4.39 & 1.18 & $1,2,3$ \\
3. Project Champion & 4.23 & 1.44 & $1,2,3$ \\
4. Project Management & 4.05 & 1.08 & 1,2 \\
5. Business Plan \& Vision & 4.01 & 1.13 & 1 \\
6. Vendor Support & 3.89 & 1.21 & 2,3 \\
7. User Involvement / Training & 3.74 & 1.71 & 2,3 \\
8. Change Management & 3.51 & 1.63 & 2,3 \\
9. Business Process Reorganization & 3.33 & 1.09 & $1,2,3$ \\
10. Cooperation \& Communication & 3.17 & 1.92 & 2,3 \\
\hline
\end{tabular}

Phases: 1= Pre-Implementation, 2= Implementation, $\mathbf{3}=$ Post-Implementation 
Top Management Support, Teamwork \& Composition, and Project Champion were observed as the most CSFs by the university stakeholders in the three phases of the ERP implementation. Project Management is also important but basically during the first and second phases. The other factors are also important but the importance of the factor differs from one stage to another and subject to the nature of the implementation phase, where some factors are more important than the others across the three implementation stages, for example Business Plan \& Vision viewed as important factor but mainly in the pre-implementation phase.

Vendor Support, User Involvement \& Training, and Change Management are very critical factors during the implementation and post-implementation stages as stated by the university key stakeholders. Business Process Reorganization perceived as less important than the other factors but it must be considered across the three stages of the ERP system implementation. Cooperation \& Communication factor viewed as the least important factor among the top ten CSFs and it should be considered mostly in the last two stages of the ERP system implementation.

\section{Discussion}

According to the top management of Sohar University the implementation of ERP system is one of the most significant investments that tremendously change the way of doing business in the university. Therefore, the implementation of the new system was entirely supported and controlled by the top management and that was the most critical success factor of the ERP system project. This finding is consistent with the existing studies which found that managerial supports are critical to the success of adopting ERP system in an organisation (Kronbichler et al., 2009; Parr and Shanks, 2000; Shanks et al., 2000; Somers and Nelson, 2004).

The newly introduced ERP system had made considerable improvement in many parts of the university operations such as registration, finance, human resource, purchasing, teaching, timetabling, and examination. The project team and the key stakeholders completely understand the importance of the ERP project to the university and therefore they made every effort to complete the project successfully. This is an important message, as interdepartmental cooperation and effective communication are critical to the success of implementing ERP system in higher education institutions (Kronbichler et al., 2009; Rabaa'I, 2009; Somers and Nelson, 2004). We have also shown that key players - namely project team, project leader, and top management - are statistically significant and meaningful, confirming the study of Somers and Nelson (2004).

The new ERP system was mainly introduced to replace the legacy system that failed to guarantee a certain level of integration and communication among the key departments and faculties. The new system was adopted as a business solution that enables the university to streamline its daily business process, provide integration, enhance information access, and ensure data accuracy and integrity. These are significant benefits that the ERP system delivers and part of the overall system performance. Our findings can help educational leaders or divisional managers to justify investment in ERP systems in higher education institutions. Nevertheless,

International Journal of Management and Applied Research, 2016, Vol. 3, No. 1 
there are some other technical and organizational concerns that may lead to poor performance and still lingering.

\section{Conclusion}

The scope and complexity of the ERP system project requires several supportive factors in each implementation phase that crucial in one of the stages or across the three implementation stages. This study has examined 10 CSFs and ranked them based on to the importance of each factor for the ERP project. The classification of the CSFs in each implementation phase was based on the nature of the stage and on the need of the particular factor in each phase. The abandon of any factor that is important in a particular stage might result in undesirable consequences.

Universities have a unique nature and unique needs that require them to learn from each other's experience. Sohar University case will assist other education institutes in the higher education sector to plan better and to give the appropriate priority to each CSF in each particular phase of the ERP system implementation and avoid same mistakes. One of the major concerns that Sohar University tackled with the ERP system was the Business Process Reorganization factor which requires high level of customization in the ERP system.

This high level of customization derived mainly because Sohar University has slightly different teaching approach of other local, regional, and international universities. ERP vendors usually provide "Best Practice" to ensure the international standard of business process in the university setting. If the university has a different way of doing business and difficult to adjust its business process then the university should be ready to face high level of customization which is not preferable by most of ERP vendors.

The greatest limitation of this research is its generalisability. Given the nature of single case study, its generalisability of research results is very limited. Nonetheless, this research sheds light on one of the key educational institutes in Oman. Future research could conduct multiple case studies, in many different universities or countries, to draw more refined conclusions regarding factors that are critical to the successful implementation of ERP system.

\section{References}

1. Al-Mashari, M., Ghani, S. K., \& Al-Rashid, W. (2006), "A study of the Critical Success Factors of ERP implementation in developing countries", International Journal of Internet and Enterprise Management, Vol. 4, No. 1, pp. 68-95. https://doi.org/10.1504/IJIEM.2006.008866

2. Bala, H., and Venkatesh, V. (2013), "Changes in Employees' Job Characteristics during an Enterprise System Implementation: A Latent Growth Modeling Perspective”, MIS Quarterly, Vol. 37, No. 4, pp.1113-1140.

3. Beekhuyzen, J., Goodwin, M., and Nielsen, J. L. (2002). "ERP in universities: The Australian explosion", Proceedings of the 13th Australian Conference on Information Systems (ACIS), Melbourne, Australia. Available from: 
http://eprints.qut.edu.au/34148/1/34148.pdf [Accessed on 2 May 2016].

4. Beheshti, H. M. (2006), "What managers should know about ERP/ERP II", Management Research News, Vol. 29, No. 4, pp. 184-193.

https://doi.org/10.1108/01409170610665040

5. Burca, S. D., Fynes, B., and Marshall, D. (2005), "Strategic technology adoption: extending ERP across the supply chain", The Journal of Enterprise Information Management, Vol. 18, No. 4, pp. 427-440. https://doi.org/10.1108/17410390510609581

6. Cotteleer, M. J., and Bendoly, E. 2006. "Order Lead-Time Improvement Following Enterprise Information Technology Implementation: An Empirical Study", MIS Quarterly, Vol. 30, No. 3, pp. 643-660.

7. Das, S. and Dayal, M. (2016), "Exploring determinants of cloud-based enterprise resource planning (ERP) selection and adoption: A qualitative study in the Indian education sector", Journal of Information Technology Case and Application Research, Vol. 18, No. 1, pp. 11-36. https://doi.org/10.1080/15228053.2016.1160733

8. Davenport, T.H. (1998), "Putting the enterprise into the enterprise system", Harvard Business Review, Vol. 76, No. 4, pp. 121-131

9. Dehning, B., Richardson, V. J., and Zmud, R. W. (2007), "The Financial Performance Effects of IT-Based Supply Chain Management Systems in Manufacturing Firms", Journal of Operations Management, Vol. 25, No. 4, pp. 806-824. https://doi.org/10.1016/j.jom.2006.09.001

10. Feeny, D. F. and Willcocks, L. P. (1998), "Core IS capabilities for exploiting information technology", Sloan Management Review, Vol. 39, No. 3, pp. 9-21.

11. Finney, S. and Corbett, M. (2007). "ERP implementation: a compilation and analysis of critical success factors", Business Process Management Journal, Vol. 13, No. 3, pp. 329-347. https://doi.org/10.1108/14637150710752272

12. Gargeya, V.B. and Brady, C. (2005), "Success and failure factors of adopting SAP in ERP system implementation", Business Process Management Journal, Vol. 11, No. 5, pp. 501-516. https://doi.org/10.1108/14637150510619858

13. Karimi, J., Somers, T. M., and Bhattacherjee, A. (2007), "The Role of Information Systems Resources in ERP Capability Building and Business Process Outcomes", Journal of Management Information Systems, Vol. 24, No. 2, pp. 221-260. https://doi.org/10.2753/MIS0742-1222240209

14. Katerattanakul, P., Hong, S. and Lee, J. (2006), "Enterprise resource planning survey of Korean manufacturing firms", Management Research News, Vol. 29 No. 12, pp. 820-837. https://doi.org/10.1108/01409170610717835

15. King, W. R. (2005), "Ensuring ERP Implementation success," Information Systems Management, Vol. 22, No. 3, pp. 83-84. https://doi.org/10.1201/1078/45317.22.3.20050601/88749.11

16. Kronbichler, S. A., Ostermann, H., and Staudinger, R. (2009), "A Review of Critical Success Factors for ERP-Projects", The Open Information Systems Journal, Vol. 3, pp. 14-25. https://doi.org/10.2174/1874133900903010014 
17. Loh T. C. and Koh S. C. (2004), "Critical elements for a successful enterprise resource planning implementation in small- and medium-sized enterprises", International Journal of Production Research, Vol. 42, No. 17, pp. 3433-3455. https://doi.org/10.1080/00207540410001671679

18. Loonam, J. and McDonagh, J. (2005), Principles, Foundations, \& Issues in Enterprise Systems, Ideal Group Inc.

19. Morris, M. G. and Venkatesh, V. (2010), "Job characteristics and job satisfaction: understanding the role of enterprise resource planning system implementation", MIS Quarterly, Vol. 34, No. 1, pp. 143-161.

20. Nah, F. F. and Lau, J. L. (2001), "Critical factors for successful implementation of enterprise systems", Business Process Management Journal, Vol. 7, No. 3, pp. 285-296. https://doi.org/10.1108/14637150110392782

21. Park, K. and Kusiak, A. (2005), "Enterprise resource planning (ERP) operations support system for maintaining process integration", International Journal of Production Research, Vol. 43, No. 19, pp. 3959-3982. https://doi.org/10.1080/00207540500140799

22. Parr, A. and Shanks G. (2000), "A Taxonomy of ERP Implementation Approaches", presented in: 33rd Hawaii International Conference on System Sciences (HICSS), Maui, Hawaii. Available from: https://www.computer.org/csdl/proceedings/hicss/2000/0493/07/04937018.pdf [Accessed on 1 May 2016].

23. Pollock, N. and Cornford, J. (2004), "ERP Systems and the University as a "unique" organisation", Information Technology and People, Vol. 17, No. 1, pp. 31-52. https://doi.org/10.1108/09593840410522161

24. Rabaa'I, A. A. (2009), "Identifying Critical Success Factors of ERP Systems at the Higher Education Sector", presented in the Proceedings of the Third international conference on Innovation and Information and Communication Technology (ISIICT'09), Swinton: British Computer Society, available from: http://www.bcs.org/upload/pdf/ewic_iict09_s5paper2.pdf [Accessed on 1 May 2016].

25. Ranganathan, C., and Brown, C. V. 2006. "ERP Investments and the Market Value of Firms: Toward an Understanding of Influential ERP Project Variables," Information Systems Research, Vol. 17, No. 2, pp. 145-161. https://doi.org/10.1108/14637150710763568

26. Remus, U. (2007), "Critical success factors for implementing enterprise portals: A comparison with ERP implementations", Business Process Management Journal, Vol. 13, No. 4, pp. 538-552. https://doi.org/10.1108/14637150710763568

27. Schniederjans, M. J., \& Kim, G. C. (2003), "Implementing enterprise resource planning systems with total quality control and business process reengineering Survey results", International Journal of Operations \& Production Management, Vol. 23, No. 4, pp. 418-42. https://doi.org/10.1108/01443570310467339

28. Shanks, G. A. Parr, B. Hu, B. J. Corbitt, T. Thanasankit, P. Seddon. (2000) "Differences in Critical Success Factors in ERP Systems Implementation in Australia and China: A Cultural Analysis", presented in: European Conference on

International Journal of Management and Applied Research, 2016, Vol. 3, No. 1 
Critical Success Factors across the Stages of ERP System Implementation in Sohar University:

Information Systems (ECIS 2000), Melbourne, Australia, available from: www.aisel.aisnet.org/cgi/viewcontent.cgi?article $=1071 \&$ context=ecis 2000 [Accessed on 1 May 2016].

29. Somers T.M. and Nelson K.G. (2004), "A taxonomy of players and activities across the ERP project life cycle", Information and Management, Vol. 41, No. 3, pp. 257-278. https://doi.org/10.1016/S0378-7206(03)00023-5

30. Sykes, T. A., Venkatesh, V., and Johnson, J. L. 2014. "Enterprise System Implementation and Employee Job Performance: Understanding the Role of Advice Networks", MIS Quarterly, Vol. 38, No. 1, pp. 51-72.

31. Tian, F. and Xu, S. X. (2015), "How do enterprise planning systems affect firm risk? Post-implementation impact”, MIS Quarterly, Vol. 39, No. 1, pp. 39-A9. 